\title{
Introduction to Section 2
}

\section{Embodied religion and corporeal religious experiences}

The human body is the primordial location in which religion "takes place" (Smith 1987). The body transmits, embodies, and transmogrifies religious ideas, it expresses concepts of the divine and religious dimensions of sanctity, of physical and mental health, and of life and death. Since it is "the body that gives pleasure and pain”, it "also limits what humans can experience” (Furey 2012, 12). Hence, bodily actions, together with the sensorial abilities and corporeal cognition of humans, determine religious experiences. They influence religious practices and shape religious ideas, imaginaries, and concepts.

The return of the notion of the body to studies of religion, as both a topic and an analytical category, marked a re-acknowledgement of the importance of the bodily experience of religion, in contrast to the earlier focus on "disembodied spirits" (McGuire 1990, 294) that was a consequence of the dominance of Christian (Protestant) perspectives. In ritual theory, the "ritual body" (Bell 1992, title of ch. 5) has been operationalized for the understanding of religious practices and has also found its way into anthropologically oriented studies (e.g. Stewart and Strathern 2001; Droogers 2008, esp. 456-458). Drawing on Merleau-Ponty's phenomenology, the more recent "lived religion" approach focuses on the embodied practitioners of religion and on the embodiment of religious practices (e.g. Csordas 2004; Dreyfus and Dreyfus 1999; McGuire 2008; Morgan 2015; Petridou 2017a), while scholars interested in the aesthetic or sensorial dimensions of religions, religious (image-) objects, and media have also incorporated phenomenological approaches, emphasizing the embodied experiences and sensual apparatus of humans and their role in the practice of religion (Meyer 2008; Pentcheva 2010; 2017; Zito 2011). ${ }^{1}$

When we study religious phenomena - objects, texts, persons, and practices the involvement of the body itself, and its perceptions and conceptions, opens up a view onto questions concerning the basic conditions underlying religion: How is the body referred to in religious contexts? What roles are played by bodily

1 For the role of experiences, see the introduction and the contributions in the Section 1 in this volume on "Experiencing the religious". I thank Paul Scade for copy-editing the text. 
sensations such as pain, by emotions and feelings such as happiness and fear, and by movements of the body? How is the body of a holy person conceptualized in comparison to the bodies of regular people? And how does a view of the body as a locus of religion alter views on the relations between humans and deities; between the dedication, the dedicator, and the recipient deity; or between a narrative, an object, and a ritual practice?

\section{Lived ancient religion and the body}

The "lived ancient religion" approach (LAR) is interested in "religion in the making" (Albrecht et al. 2018) from a "bottom up" perspective and in the situational and performative dimensions of ritual practices. As such, the "lived ancient religion" approach has, from its beginning, embraced the idea of embodiment. Besides the notions of "experience" and "culture in action" (Rüpke 2011) as conveying the culturally-coded meanings and experiences which form religion, the "somatic turn" in religious studies and the history of religion is acknowledged as falling within the phenomenological horizon of the "lived ancient religion" approach. ${ }^{2}$ Embodiment as practice and concept connects materiality to corporeal experience, two dimensions of religion that are central to the field of contemporary religious studies (McGuire 1990; Boivin 2009) and which have been applied successfully in the various "lived ancient religion" projects on the religious phenomena of the ancient Mediterranean (e.g. Raja and Weiss 2015; 2016; Rieger 2016; Petridou 2017b).

Bodily integrity and activity are the basis of both a functioning self and the place of the individual in their social and material environment. In turn, the functions of the body - fertility, reproduction, and physical and psychic integrity - are the goods and needs that gods are made for, and addressed in pursuit of, in almost every religion of the past and present. What, then, is the role of the body in practicing, experiencing, and, thus, living religion? The body - either human, heroic, or divine - is pivotal in its appearance, characteristics, and dispositions in religious narratives, representations, and imagery. Restrictions on bodily functions or needs through laws of purity, ascetic

2 See as a recent outcome of the "somatic turn" in religious studies the monograph by Yudith K. Greenberg (2017) on the "body in religion" where topics like "representing”, "celebrating", "disciplining" or "modifying" the body in various socio-cultural or socio-religious contexts are dealt with. 
practices, or food consumption form, cultivate, and sustain the (religious) body. Illnesses and malfunctions of the body are recurring reasons for addressing the gods, but are also a means by which humans can come closer to their deities. Religious experiences happen through sensory experiences of the body, supported by modifications or regulations that hinder or increase sensitivity. The bodily groundedness of the human being can be transgressed through religious practices, while death as the end of the physical body is insuperable and, as such, is something that is often negotiated in religious practices. Practices surrounding death, the treatment of deceased bodies, and the veneration of the dead are at the core of religious conceptions in many societies and the basis of the idea of the existence of transcendent (or transcended) agents - ancestors or deities.

An approach that focuses on embodied religion accounts for the bodies that religious specialists, saints, deities, worshippers, and dedicants have and act with. If not their own bodies, they deal with and address the bodies of others (the deceased, the deity), operationalize them (body part dedications, mimicking of body parts, pain), or distribute and extend them through representations, objects, or narratives.

Texts and persons, food and dedicatory objects, architecture and initiation, imagery and martyrs in the Mediterranean between the 4th century BCE and the 5th century CE are the focus of the papers in this section. The section starts from the preconditions of embodiment and lived religion, supported by Bill Brown's “Thing Theory" (Brown 2001; 2003) and Merleau-Ponty's supposition that the "body is a thing among things" (Merleau-Ponty 1964, 163). Considering things and their materiality in the context of Brown's theory offers a key that allows us to explore not only objects, but also bodies, body-parts and remains, bodily extensions or prostheses, and body-modifications. In Brown's view, material artifacts become "things" when they stop working for us and when they are removed from their natural/original environment and situated in new contexts of meaning. This view dovetails nicely with the emphasis on a lived ancient religion approach to the situational meaning of material artifacts in religious contexts.

Seeing bodies or body parts as objects once they are removed from their primordial context enables us to unravel the agency of body parts that are involved in religious acts. The limbs, fluids, or pieces that are dissociated from the entity of the body, but also the body as an entity in pain, can gain new and varied agency in their interaction with groups of worshippers, dedicants, or other objects participating in religious practices (images, places), and, last but not least, in their interaction with deities. 


\section{Extended, truncated and fragmented bodies: religious expressions of the body}

The four contributions in this section revolve around two major strands of inquiry: (1) the conceptualization and states of the body, and its role in and for religious practices and experiences; and (2) body parts, their materializations, and their significance. The authors deal with pain, illness as initiation, mimetic food and food consumption, proxies and performances, extended agency, and the personhood of saintly figures.

Emma J. Graham ("Hand in hand: Rethinking anatomical votives as material things”) examines so-called anatomical votives from Republican Italy - dedications of body parts made of terracotta - through the lens of the various materialities they represented and with which they played. With a focus on the hand as votive, and drawing on theories about agency and performative dimensions of religious practice, she starts from "the tactile and haptic affordances" (Graham 225; cf. Hamilakis 2013). Analyzing the terracotta hands in assemblages from midRepublican sacred places (late 4th to early 1st century BCE) as representatives of body parts and objects that perform rituals activities, Graham discusses the ways in which "objects, combined with bodily motion, sensory perception, temporality, and spatiality, acted as 'instruments of knowledge' (Chidester 2005, 57), in this case instruments of religious knowledge" (Graham 211; cf. Draycott and Graham 2017). The result of her investigation is an understanding of the tripartite role that (terracotta) hands could play in the performative acts of rituals: "a terracotta votive hand can be acknowledged to have affected the body on at least three different levels: as a material thing, as a representational thing (votive hand), [... and] as a thing that was simultaneously a material and representational proxy for a real hand (described here as a 'hand')" (Graham 226). This interpretation of anatomical votives differentiates three levels of meaning that are intertwined but which all refer to the body and then brings these to bear on our understanding of the agency of these dedicational objects in ritual practices.

The topic of Georgia Petridou's contribution ("The 'lived' body in pain: illness and initiation in Lucian's Podagra and Aelius Aristides' Hieroi Logoi”) is the relation of bodily pain to the ritual practice of initiation, a religious act that aims to achieve a closeness to the god or gods. Petridou sheds light on narratives of both ill and healthy bodies, and especially the role played by pain, by drawing on narratives about gout from the 2nd century CE. She argues that illness, but more specifically the pain generated by illness, was used in the religious (con)texts of this period, during which there was a particular interest in the body as the point of access for initiation (myesis), showcased in the mysteries of 
Asklepios or neos Asklepios Glykon (cf. Good Delvecchio et al. 1992; King 2018). The "cultural conception of illness as initiation" (Petridou 238) is present "in both narratives". While the healing of a suffering body is paired with initiation in the uniquely personal literary reports of Aelius concerning his unusual relationship with Asklepios, in the parodistic Podagra it is the illness that is tied to the initiatory rites. Pain serves in these narratives as a "facilitator ... to the allimportant process of initiation ..." (Petridou 239). The sacred and the suffering are both ineffable and elusive, yet the body and its sensorial apparatus are the place in which both are experienced (cf. Sullivan 1990). Acknowledging these parallels, the close relationship between the religious practices of individuals and the body as the location of illness, disabilities, and the experience of pain, comes to the fore in this "lived ancient religion-friendly" approach to the subject.

The triangle of religion, practices, and the body are deepened in the contributions of Heather Hunter-Crawley and Nicola Denzey Lewis, which deal with Christian saints and their veneration. In these chapters, religious expression and embodiment are placed in extraordinary bodies, or in the extraordinary situations in which bodies find themselves, as well as in mimetic representations of these bodies.

The Syrian Saint Simeon the Elder (5th century CE), perched on his column, is seen as a body in refraction. Heather Hunter-Crawley ("Divinity refracted: extended agency and the cult of Symeon Stylites the Elder") examines the agency, influence, and power of Simeon as a Christian holy person, starting from a sensory archaeology and ideas of extended personhood (Malafouris 2008; Hamilakis 2013). Iconographical representations of the saint, souvenir tokens made at the church at Qal'at Sem'an, and the location itself are all analyzed as evidence of the saint's distributed agency (cf. Cox-Miller 2009). Arguing against a dichotomic view of the bounded body, Hunter-Crawley finds attestations of the importance of the saint's body that go beyond its physical materiality: the saint not only lived on a column, but also iconographically became a column, his body transformed in its depiction. The tokens, in turn, made from the dust of the place, are materially identical with the saint. Hunter-Crawley convincingly claims that the tokens are not loaded with significance through the touch of the saint (the "contagion model”, p. 264) but, rather, that they become the saint through their localized materiality. The agency of his body was no less strong than the agency of the tokens, when we apply the idea of the extended or distributed body and personhood of the saint. The matter of the tokens and the column, when taken in parallel to the saint's body, can be compared to the significance of the terracottahands and their threefold meaning, as developed in the contribution of Graham.

Nicola Denzey Lewis's contribution ("Food for the body, the body as food: Roman martyrs and the paradox of consumption”) leads us a step further in 
this direction, with the saints' being ingested. As in Petridou's argument, Denzey Lewis emphasizes the inextricable relationship between bodily pain and religious experience. Yet here it is pain in a figurative, rather than a literal, sense, since tortured body parts or liquids expressing the pain of the saints are represented in mimetic food that is consumed by the Christian believers. Denzey Lewis scrutinizes the "use" and the role of the bodies of the saints as food for the bodies of practitioners and participants in the saints' festivals (cf. Bynum 1994; Counihan 1999). The point of departure for her argument is the variety of foodstuffs used in the veneration of catholic saints who had been martyrs, which were either given the shape of bodily parts or were understood as mimetically represented in liquids such as milk. The relation of the martyrs' bodies to the body as food is discussed first in the context of the modern tradition of the minne di Sant'Agata (breast-like cakes) and then in relation to martyr narratives from late antiquity in order to examine what purpose the likening of the body of the saint to foods might have fulfilled (for example, the milk of Santa Perpetua or the body of Polycarp as bread). Denzey Lewis shows how the cruelty involved in the stories about the suffering of the saint and his or her body, that which makes the saint a saint, are somehow inverted in the consumption of their bodies as food (cf. Cobb 2016). Two interpretative theories are deployed: "The first theory is that the human body is presented as food (usually meat, sometimes milk) because it is meant to evoke shock and disgust. The second is that the human body is presented as food (usually bread, sometimes meat or milk) because it is part of a 'distancing mechanism' that mitigates the horror of martyrdom” (Denzey Lewis 296). Between distance and disgust lies the entire tasty world of the consumption of the food by believers - lived religion perpetuated in festive food that is "deeply and richly textured, satisfying and fully experiential” (Denzey Lewis 303).

Drawing on diverse source materials that range from anonymous dedicators in Republican Italy, through Greek intellectuals of the Second Sophistic, to pilgrims and saints in late antique Syria, and diachronically from late antique martyrologies to the work benches of Sicilian pasticcerie, the contributions in this section show just how important the body and embodiment were to religious practices. Bodily practices and experiences, as these chapters reveal, can bring humans closer to god or saints closer to their pilgrims. Bodily proxies and mimicking turn out to be strategies used both to communicate and to live religion. Coping with or creating refracted, distributed, and transformed or tortured bodies in multifarious materializations (tokens, cakes, imagery, pain, texts) is the very first way in which human beings interact and communicate with, or even gain closer proximity to divine agents. Indeed, in the most extreme case of martyrdom, they become precursors of the divine agents. The transformation and 
representation of the body or body parts in other materialities is not only a medium for religion but is embodied religion.

\section{Bibliography}

Albrecht, Janico et al. 2018. 'Religion in the Making: the Lived Ancient Religion Approach', Religion 48.1-26.

Bell, Catherine 1992. Ritual Theory, Ritual Practice. Oxford.

Boivin, Nicole 2009. 'Grasping the Elusive and Unknowable: Material Culture in Ritual Practice', Material Religion 5. 266-287.

Brown, Bill 2001. 'Thing Theory', Critical Inquiry 28. 1-22.

Brown, Bill 2003. A Sense of Things. Chicago.

Bynum, Carolyn Walker 1994. The Resurrection of the Body, 200 AD - 1200 AD. New York.

Chidester, David 2005. 'The American Touch: Tactile Imagery in American Religion and Politics.' In The Book of Touch, ed. Constance Classen. Oxford. 49-65.

Cobb, L. Stephanie 2016. Divine Deliverance: Pain and Painlessness in Early Christian Martyr Texts. Berkeley.

Counihan, Carole M. 1999. The Anthropology of Food and the Body: Gender, Meaning and Power. New York.

Cox-Miller, Patricia 2009. The Corporeal Imagination: Signifying the Holy in Late Ancient Christianity. Philadelphia, PA.

Csordas, Thomas 2004. 'Asymptote of the Ineffable: Embodiment, Alterity, and the Theory of Religion', Current Anthropology 45. 163-184.

Draycott, Jane; Graham, Emma-Jayne (eds) 2017. Bodies of Evidence: Ancient Anatomical Votives Past, Present and Future. London.

Dreyfus, Hubert L.; Dreyfus, Stuart E. 1999. 'The Challenge of Merleau-Ponty's Phenomenology of Embodiment for Cognitive Science.' In Perspectives on Embodiment: The Intersections of Nature and Culture, ed. Gail Weiss, Honi Fern Haber. New York. 103-120.

Droogers, André F. 2008. 'As Close as a Scholar Can Get: Exploring a One-Field Approach to the Study of Religion.' In Religion: Beyond a Concept, ed. Hent de Vries. New York. 448-463.

Furey, Constance M. 2012. 'Body, Society, and Subjectivity in Religious Studies', Journal of the American Academy of Religion 80. 7-33. doi:10.1093/jaarel//fr088.

Good Delvecchio, Mary-Jo et al. (eds) 1992. Pain as Human Experience: An Anthropological Perspective. Berkeley.

Greenberg, Yudith Kronberg 2017. The Body in Religion: Cross-Cultural Perspectives. London/ Oxford.

Hamilakis, Yannis 2013. Archaeology and the Senses: Human Experience, Memory, and Affect. Cambridge.

King, Daniel 2018. Experiencing Pain in Imperial Greek Culture. Oxford.

Malafouris, Lambros 2008. 'Is It "Me” or Is It “Mine”? The Mycenaean Sword as a Body-Part.' In Past Bodies, ed. Dusan Boric, John Robb. Oxford. 115-123.

McGuire, Meredith B. 1990. 'Religion and the Body: Rematerializing the Human Body the Social Sciences of Religion', Journal for the Scientific Study of Religion 29. 283-296. 
McGuire, Meredith B. 2008. Lived Religion. Faith and Practice in Everyday Life. Oxford.

Merleau-Ponty, Maurice 1964. 'Eye and Mind.' In The Primacy of Perception and other Essays on Phenomenological Psychology, the Philosophy of Art, History, and Politics. Evanston, IL. 159-190. ['L'œil et l'esprit' 1961. Paris].

Merleau-Ponty, Maurice 2012. Phenomenology of Perception. Trans. Donald Landes. London. [Phénoménologie de la perception 1945. Paris].

Meyer, Birgit 2008. 'Religious Sensations: Why Media, Aesthetics, and Power Matter in the Study of Contemporary Religion.' In Religion: Beyond A Concept, ed. Hent de Vries. New York. 704-723.

Morgan, David 2015. 'Material Culture and Embodiment in American Religion.' In Oxford Research Encyclopedias: Religion. doi: 10.1093/acrefore/9780199340378.013.32.

Pentcheva, Bissera V. 2010. The Sensual Icon: Space, Ritual, and the Senses in Byzantium. University Park, PA.

Pentcheva, Bissera V. 2017. Hagia Sophia: Sound, Space, and Spirit in Byzantium. University Park, PA.

Petridou, Georgia 2017a. 'What is Divine about Medicine? Religious Imagery and Bodily Knowledge in Aelius Aristides and Lucian', Religion of the Roman Empire 3.2. 242-264. doi: 10.1628/219944617X15008820103333.

Petridou, Georgia 2017b. 'Introduction: Lived Ancient Religion and the Body', Religion in the Roman Empire 3.2. 137-142. doi: 10.1628/219944617X15008820103405.

Raja, Rubina; Weiss, Lara 2015. 'The Role of Objects: Meaning, Situations and Interaction', Religion in the Roman Empire 1.2. 137-147. doi: 10.1628/219944615X14296073073494.

Raja, Rubina; Weiss, Lara 2016. 'The Significance of Objects: Considerations on Agency and Context', Religion in the Roman Empire 2.3. 297-306. doi: 10.1628/ 219944616 X14770583541445.

Rieger, Anna-Katharina 2016. 'Waste Matters: Life Cycle and Agency of Pottery Employed in Greco-Roman Sacred Spaces', Religion in the Roman Empire 2.3. 307-339. doi: 10.1628/ 219944616 X14770583541481.

Rüpke, Jörg 2011. 'Lived Ancient Religion: Questioning “Cults” and “Polis Religion”', Mythos 5. 191-204.

Smith, Jonathan Z. 1987. To Take Place: Toward Theory in Ritual. Chicago.

Stewart, Pamela J.; Strathern, Andrew 2001. Humors and Substances: Ideas of the Body in New Guinea. Westport, CT/London.

Sullivan, Lawrence E. 1990. 'Body Works: Knowledge of the Body in the Study of Religion', History of Religions 30. 86-99.

Zito, Angela 2011. 'Body', Material Religion 7. 18-25. doi: 10.2752/ $175183411 X 12968355481818$. 